\title{
Kant's use of travel reports in theorizing about race - A case study of how testimony features in natural philosophy
}

\author{
Huaping Lu-Adler \\ Georgetown University, United States
}

\section{A R T I C L E I N F O}

\section{Keywords:}

Kant

Testimony

Historical cognition

Rational cognition

Travel reports

Race

\begin{abstract}
A B S T R A C T
A testimony is somebody else's reported experience of what has happened. It is an indispensable source of knowledge. It only gives us historical cognition, however, which stands in a complex relation to rational or philosophical cognition: while the latter presupposes historical cognition as its matter, one needs the architectonic "eye of a philosopher" to select, interpret, and organize historical cognition. Kant develops this rationalist theory of testimony. He also practices it in his own work, especially while theorizing about race as a subject of natural philosophy. In three dedicated essays on this subject, he treats race from the standpoint of a philosophical investigator of nature (Naturforscher), who (as Kant puts it in the first Critique) learns from nature "like an appointed judge who compels witnesses to answer the questions he puts to them." This view underwrites Kant's use of travel reports (a type of testimony) in developing and defending his theory of race.
\end{abstract}

\section{Introduction}

There are just a few dedicated studies on Kant's account of testimony. Their shared concern is to show that he can regard testimony as a source of knowledge in a way that is compatible with his emphasis on intellectual autonomy (Gelfert, 2006; Mikalsen, 2010; Newton, 2014; Shieber, 2010). None of them considers how Kant uses testimonies in his own work or the fact that testimony/witness is one of the many legal metaphors he employs to illustrate various aspects of reason. As a result, they have largely overlooked a crucial feature of testimony for Kant, namely its subservience to reason. My goal is to foreground this feature, as reflected both in Kant's theory of testimony (section 2) and in how he uses travel reports, a form of testimony, when theorizing about race as a subject of natural philosophy (section 3 ). ${ }^{1}$

I begin by locating witnesses in Kant's metaphorical court, as completely passive in relation to such other characters as the judge and the lawyers (section 2.1). This feature manifests itself both in Kant's basic theory of testimony and in how he uses the metaphorical relation between the judge and witnesses to characterize how reason approaches nature in one case and addresses certain dogmatic claims in another (section 2.2).

Specifically, testimonies are subservient to reason in two ways. First, witnesses are compelled to answer precisely the questions that the judge,
Kant's metaphor for an authoritative reason, asks them (in the civil-law system) or permits the lawyers to ask (in the common-law system). This point is exemplified in how a vast amount of modern travel reports, from which Kant would draw materials to theorize about race as a natural philosopher, were generated during the preceding century or so: a systematic global data collecting was carried out under the explicit guidelines set down by the Baconian natural philosophers. In the process, skin color emerged as a special topic about which further data would be solicited from travelers worldwide; natural-philosophical interest in this topic deepened as a result (section 3.1).

It is against this backdrop that Kant privileges the reports by modern travelers as generally more reliable than ever before in history (section 2.2). Furthermore, his use of such reports exemplifies the second way in which testimonies are subservient to reason: it is up to the philosophical/rational investigator to decide what kind of uptake a given testimony can have. Studying the heredity of skin color as a natural philosopher, Kant is primarily interested in defending his own mode of explanation against the competitors on rational grounds. Only then can one decide, he suggests, what to make of all the relevant travel reports (section 3.2). This approach, I shall point out, can be deeply problematic when the subject matter involves actual humans (section 4).

E-mail address: h1530@georgetown.edu.

1 By 'natural philosophy,' I mean that which investigates natural phenomena with the goal to uncover their law-governed natural causes. 


\section{Kant's theory of testimony}

\subsection{Witness/testimony as a legal metaphor}

Kant often invokes legal metaphors to convey important philosophical points. ${ }^{2}$ Besides his well-known distinction between quid facti and quid juris (A84-5/B116-17), ${ }^{3}$ there are familiar characters like the legislator (Gesetzgeber), judge (Richter), and jurors (Geschworenen). Lesser known are witnesses (Zeugen) and lawyers (Advocaten). To see how testimony (Zeugniß) figures in Kant's metaphorical court (Gerichtshof), it will be instructive first to consider how he views the judge and lawyers.

In Kant's view, a judge should not merely possess juridical knowledge in abstracto; he must also be able to apply it properly in concreto (A134/ B173; Eth-Vigil, 27:534-35). ${ }^{4}$ This includes "selecting what is exactly appropriate in a given case," the "talent" for which is regrettably "very rare" among the judges (Anth, 7:228). A lawyer may then play a role, either assisting or impeding the judge in this regard.

The lawyer who arrives with many principles that are supposed to prove his assertion makes the judge's sentence very difficult, because he himself is only fumbling around. But if the lawyer, after clarifying what he wants to say, knows how to find the point about the matter (for there is only one), then the issue is quickly settled, and the verdict of reason follows by itself. (Anth, 7:228)

Lawyers in real life, as Kant sees them, are more likely to use their analytical acumen to trick the judge than to help him arrive at a just verdict. They employ rhetoric devices and "imperceptibly try to attack the judge on his weak side and thus try to win him over through cunning" (Anth-Mron, 25:1281). They "try to dupe judges," for instance, by making complex juridical principles deceptively simple and uncontroversial (25:1236). They like to defend their side through "a lawyer's proof, which takes advantage of an opponent's carelessness and gladly permits a misunderstanding of the law in order to build the case for his own unjust claims on the refutation of the other side" (A430/B458; see Eth-Vigil, 27:533).

Kant deems those judges weak (schwach) who fail to see that some lawyers are mere "shyster[s]" (Eth-Collins, 27:359) or who, "without getting into the business deeply and in order to get rid of it quickly, just grasp at the first argument that occurs to them and decide accordingly" (A789/B817). A genuine judge, who is not easily tricked by the sophistical lawyers, must be a legal expert, who knows the laws as a system founded on certain "immutable principles" (MS, 6:229; see Eth-Collins, 27:279). Such a judge may be called a "philosophic jurist," one who also philosophizes (MS, 6:280n.; see Lo-Wien, 24:799-800). If "judicial authority" lies with the "person of the judge" (MS, 6:313), presumably only the judge as a philosophic jurist can bring justice through his verdicts. For justice is "the idea of judicial authority," whereby verdicts are willed "in accordance with universal laws that are grounded a priori" (MS, 6:334).

How would witnesses fit into this picture? Consider Kant's following statement in the Preface to the 1787 edition (B Preface) of the Critique of Pure Reason.

Reason, in order to be taught by nature, must approach nature with its principles in one hand ... and, in the other hand, the experiments thought out in accordance with these principles-yet in order to be instructed by nature not like a pupil, ... but like an appointed judge who compels witnesses to answer the questions he puts to them. Thus ... what

\footnotetext{
${ }^{2}$ See Møller, 2020 for a systematic study of Kant's legal metaphors, with a brief consideration of testimony at 87-9.

${ }^{3}$ References to Kant's Critique take the standard A/B form, corresponding to its first (1781) and second (1787) editions. References to his other works are to the volume and pagination of Immanuel Kant: Gesammelte Schriften (Berlin, 1902-). Abbreviations and translations used are specified in the bibliography.

${ }^{4}$ I preserve Kant's practice of using male pronouns, in order not to paper over the fact that he would only see men as fit to be judges, lawyers, and even competent witnesses.
}

reason would not be able to know of itself and has to learn from nature, it has to seek in the latter (though not merely ascribe to it) in accordance with what reason itself puts into nature. (Bxiii-xiv, italics added)

Here, the judge plays the proactive role of an investigator, with no lawyers in the picture. This suggests that Kant is referring to the civil-law system, where the judge uses an inquisitorial procedure to establish facts by questioning witnesses. The judge needs to learn from witnesses, because he is not personally acquainted with the facts that he needs to determine the case at hand (Lo-Wien, 24:897). Meanwhile, he should be prepared in advance by, say, studying the case and reflecting on applicable legal codes, so that he can pose appropriate questions to obtain the most pertinent information from witnesses.

When Kant mentions witnesses again later in the Critique (while discussing speculative theology), he switches to the common-law system.

[Given what has been established about possible experience] we might have been able to dispense with our painstaking examination of the dialectical witnesses which a transcendent reason brings forward on behalf of its pretensions; for we already knew beforehand with complete certainty that all their allegations, while perhaps honestly meant, had to be absolutely null and void, because they dealt with information which no human being can ever get. (A703/B731; see A636-37/B664-65)

In the common-law system, an adversarial procedure is employed to determine the facts. The opposing parties compete before the judge (and the jury). A lawyer can bring forward and cross-examine witnesses on behalf of his party. The judge may rule that a testimony is impertinent or null. In particular, a testimony may be dismissed in advance if it claims to establish the existence of a supersensible being, because we cannot encounter any such being in experience (Lo-Blom, 24:247). Nonetheless, Kant's judge in the present case allows the party that claims knowledge of the supersensible to call its witnesses. This helps to establish a precedent for future rulings, which is a hallmark of the common-law system, by foregrounding the dialectic illusion in the pretended knowledge of the supersensible. Since such an illusion "can fool even the most rational, ... and so will be present in the future too," Kant submits, it is advisable to "draw up an exhaustive dossier, as it were, of these proceedings and store it in the archives of human reason, so as to prevent future errors of a similar kind" (A703-4/B731-32).

In spite of their differences, both the civil-law and common-law systems grant no more than a severely limited, purely passive role to witnesses. How they are questioned, what kinds of facts are sought through their testimonies, and what uptake such facts may receive- - these largely depend on decisions made by such other characters as the judge and lawyers. We will see this point being reflected in Kant's theory of testimony (section 2.2) and then again in how he (section 3.2), as well as some of his predecessors (section 3.1), uses testimonies (travel reports) in natural philosophy.

\subsection{Testimony as "historical cognition"}

Kant treats testimony as a basic source of cognition (Lo-Blom, 24:30; Lo-Wiener, 24:895-97). In terms of content, a testimony represents a fact that has occurred and has been directly experienced by someone. Accordingly, a witness is one "who asserts an experience." By contrast, "one who asserts universal judgments of reason as true is not a witness" and such assertions are not testimonies (Lo-Blom, 24:244).

Kant is thereby alluding to the distinction between historical and rational cognitions. He gives two versions of this distinction. Subjectively, I cognize something historically if I deem it true just because someone has told me so; by contrast, my cognition is rational if I have drawn it "from principles of reason." Objectively, a cognition is historical if it is possible only on the basis of experience (either one's own or others')—as in history and geography; it is rational if it is possible only as a "cognition ex principiis, which has been drawn from grounds a priori"-as in 
philosophy and mathematics. An objectively rational cognition may nevertheless be subjectively historical, which Kant considers harmful in philosophy. For then one is not philosophizing, but merely imitating others (Lo-Wien, 24:797, 830; see A836-37/B864-65; JL, 9:22, 25; Lo-Blom, 24:52-3, 99-100).

Lacking either historical or rational cognition in the objective sense amounts to ignorance. Lacking historical cognition-for example, not knowing the existence of something-is material ignorance. By contrast, one is formally ignorant for not understanding the "grounds" of a thing-either what they are or how the thing in question follows from them (Lo-Blom, 24:66). Kant urges that we extend our cognition on both fronts. First off,

Historical cognition must lay the ground for all rational cognition. ... The brooder who shuts himself up in his room and wants to attain much rational cognition will not get far if he has not first acquired historical cognition by means of experience from books, or from contact, from association with other people. (Lo-Blom, 24:49, translation amended)

In particular, we need to acquire historical cognition through testimonies, because our own experience is spatiotemporally limited.

Thus we extend our knowledge through the testimony of others, as if we had lived through the world's entire past. And we increase our knowledge of the present through testimony concerning foreign and remote countries, as if we had lived there ourselves. (PG, 9:159; see JL, 9:77-8; Lo-Blom, 24:245; Lo-Wien, 24:870) ${ }^{5}$

Meanwhile, it is not enough just to accumulate historical cognitions. One who possesses "gigantic erudition" may still be like a one-eyed Cyclops, missing "the eye of true philosophy, by means of which reason suitably uses this mass of historical knowledge" (Anth, 7:227; see Lo-Wien, 24:818). Indeed, from Kant's perspective, we need the eye of philosophy even as we gather empirical information:

we need to become acquainted with the objects of our experience as a whole. Thereby our knowledge is not an aggregation but a system; ...

... Contact with people and travel broaden all our knowledge. ... if we are prepared in advance by [appropriate] instruction, then we have a conceptual whole [ein Ganzes, einen Inbegriff von Kenntnissen] by means of which we can learn about people. We are then in a position to allocate to every experience its class and its place within the whole. (PG, 9:158; see Anth, 7:120)

The Inbegriff that one needs in advance is a certain "architectonic concept," in reference to which one may then gather empirical data methodically—so as to facilitate the "understanding of connections," which is a form of rational cognition (PG, 9:158).

Given this account of the relation between historical and rational cognitions, we may recap three points about how the judge, representing reason, relates to witnesses/testimonies in Kant's metaphorical court.

(1) The judge establishes facts by directly interrogating witnesses or through lawyers' cross-examinations of them. This is a process of obtaining objectively historical cognition, which will serve as the material basis for judicial deliberation (rational cognition).

(2) The judge must be prepared in advance, so as to interrogate witnesses skillfully or to monitor lawyers' cross-examinations effectively. This preparation already presupposes a certain philosophical understanding (to be elaborated next), which allows the judge to form a working hypothesis, for instance, to guide his subsequent interactions with the witnesses/lawyers.

\footnotetext{
${ }^{5}$ No wonder Kant considers it an offense to the entirety of mankind and a violation of "the right of humanity" if someone "publishes a false report" (EthCollins, 27:447-48).
}

(3) How the resulting testimonies figure in the judge's deliberation is also a matter of philosophical understanding. To connect them properly with everything else relevant to the case, he must know what laws (or precedents) are applicable and how to interpret them. And this knowledge must be rational subjectively speaking. Otherwise, "if the jurist knows jurisprudence merely historically, then he is fully ruined [verdorden] as a genuine judge" (JL, 9:22).

All these points, as we shall see, will manifest themselves in how Kant uses testimonies (travel reports) in theorizing about race as a natural philosopher.

What will also be relevant is Kant's reflection on the attributes of credible witnesses. This reflection is important because a truth-seeker's belief in a testimony must be "seeing belief" (as opposed to "blind belief"), which rests on a prior scrutiny of the witness's credibility (Lo-Blom, 24:249). On Kant's account, a credible witness must possess the basic "logical" attributes that enable him to "obtain an experience." These include the capacity for "rational reflection" and the ability to preserve the obtained experience faithfully in memory and then communicate it to others accurately. The witness must also have the "moral" attribute of a sincere will to report his experience truthfully. Furthermore, as a "pragmatic" matter, the witness must be someone who would not expect advantages from giving a false report (Lo-Blom, 24:244-45).

Generally, Kant reasons, a "learned man" makes a better witness than a "common man." In terms of logical attributes, the latter is easily "distracted" and "overcome by fear" and other emotions that can distort experience, less attentive and more likely to overlook things, and unable to tell others his experience in a clear and meticulous manner; furthermore, he is cavalier about lies, being "too crude to place great value on the truth." By contrast, the learned man, even if he does not tell truth as a matter of moral duty, ${ }^{6}$ he will at least do it from a sense of honor. Such is the case in modern times, Kant claims, when "everyone had to be quite exact in his reports, and if someone deviated from the truth only a bit in his writings, he was ridiculed and dishonored." For this reason, Kant trusts that his was a time when "historical belief carries with it astonishing credibility, because the witness must have so many properties in order to speak the truth." Accordingly, history and geography can be securely "grounded on the testimony of other men" (Lo-Wien, 24:898-99). In these areas, then, one may trust the learned men's testimonies as much as or, in cases that require practiced skills and trained eyes, even more than one does one's own observations (Lo-Wien, 24:891-92, 895-96; see Lo-Blom, 24:246; JL, 9:68; PG, 9:159).

Kant also holds that, where reliable reports are called for, "written information is preferable to that passed on merely by word of mouth" (PG, 9:159). This is when one cites others, which signals trust. After all, "if I did not intend to hold something to be true on the testimony of someone else, I would not cite him, i.e., call him as a witness" (Lo-Wien, 24:897). We will see Kant frequently calling others as witnesses in this way, especially when he needs evidence for his claims about human beings in faraway places. Equally noteworthy is the fact that he can find ample testimonies to cite in the first place. As we shall see next, this fact is not a mere accident.

\section{Testimony in natural philosophy: Kant's use of travel reports in theorizing about race}

\subsection{Backdrop: Baconian data collecting, and skin color as a subject of natural philosophy}

Kant's theory of race took shape against the backdrop of previous natural philosophers' collective effort to understand the world on a global scale. Particularly relevant here is the work by important seventeenth-

\footnotetext{
${ }^{6}$ Kant often uses testimony to illustrate the duty of truth telling (Eth-Vigil, 27: 487, 491, 506-7, 605).
} 
century philosophers who, seeking a systematic understanding of everything on earth from minerals to human beings, proactively mediated a systematic global data gathering. Because of this work, someone like Kant would be able to theorize about the entire humanity-not as an abstract concept, but as actual beings that populated the Earth-by drawing on copious travel reports containing detailed descriptions of non-Europeans regarding their skin color, physical form, customs, and so forth. Such reports were produced by Europeans who were in the position to "observe" the rest of the world thanks to Europe's growing trading and colonizing activities. Their testimonies were far from objective or disinterested. ${ }^{7}$ Yet most of them would be received as credible representations of facts, in reference to which natural philosophers (including Kant) would test their hypotheses, for example, about the cause of certain human differences. This seemingly uncritical reception is not a matter of blindly believing one's fellow Europeans, but reflects the institutional structure that gave those testimonial reports the overall feel of relevance and truthfulness.

My account of witnesses' passive place in Kant's metaphorical court in section 2.1 helps to demonstrate this point. In a civil-law court (the more fitting model in this case), witnesses must answer, under the oath of truth telling, only the questions posed by the judge. Suppose the judge is by all appearances a qualified philosophic jurist, an expert in the highest laws of reason who also knows how to apply them properly in concreto; he can therefore interrogate witnesses effectively, by asking precisely the questions that can induce the most pertinent testimonies from them (this pertains to point 2 that I summarized in section 2.2). In this scenario, it is only reasonable for a spectator to accept such testimonies not only as truthful but also as supplying the appropriate material basis for rational deliberation (recall the objective distinction between historical and rational cognitions). Now let Kant be the spectator. The judge who asked the right questions would be represented, first and foremost, by Francis Bacon (1561-1626) and the fellows of the Royal Society of London for Improving Natural Knowledge ("Royal Society" for short), founded on Baconian principles in $1660 .^{8}$ The witnesses would be learned travelers, all Europeans, who were well positioned to gather information about nature's products on foreign lands. In what follows, I explain how Bacon and, following him, Robert Boyle (1627-91, one of the Royal Society's founding fellows) formulated a basic set of queries, coupled with methodological instructions, to regulate the global data gathering that would give rise to the travel reports that Kant, among other natural philosophers, could mine for usable testimonial (counter-)evidence to test hypotheses about human differences.

Bacon's Novum Organum (1620, translated in Bacon, 2000), as its subtitle (sive Indicia Vera de Interpretatione Naturae) suggests, promotes a new method for interpreting nature. This method includes two parts: "the first for drawing axioms from experience; the second on deducing or deriving new experiments from axioms." The former must begin with "a good, adequate natural and experimental history," which is "the foundation of the matter" and which is a necessary first step toward a true understanding of nature insofar as we are to "discover," not "invent or imagine what nature does or suffers" (Bacon, 2000, p. 109). ${ }^{9}$ Simply put, natural philosophy presupposes an appropriate data collection. In Bacon's view, the philosophical interpreter of nature should lean on others to fulfill this preliminary task, because it can be massive, time-consuming, and costly. As he puts it in the Parasceve, ad historiam naturalem et experimentalem (1620, published together with the Novum

\footnotetext{
7 These visitors to foreign lands faced linguistic and cultural barriers, which often frustrated their attempts to gather "facts" about the inhabitants they encountered. Furthermore, most of them had already been socialized into a worldview that was full of negativities about Sub-Saharan Africans, for instance. For a comprehensive case study of the French encounter with Africans, which helps to illustrate this point, see Cohen, 1980.

${ }^{8}$ On the relation between the early Royal Society and the Baconian philosophy, see Hunter, 2007.

${ }^{9}$ This proposition will become the epigraph of Boyle, 1664.
}

Organum; translated in Bacon, 2000), there must be a division of labor: while the interpreter focuses on what "relates to the actual work of the understanding," it is up to others to compile the history that contains "an abundance of good material, which is digested for the work of the interpreter" (2000, p. 222). To be more specific,

the materials for the understanding are so widely scattered that we need to have agents and merchants (so to speak) seeking and collecting them from every corner. And in fact it is rather below the dignity of our enterprise to waste our own time on such a thing as any industrious person may do. (222-23)

This statement reflects Bacon's appreciation of the growing global reach of a rising British empire through colonization and trading. As a philosopher, he sees in this imperialist expansion an opportunity for a radical transformation of philosophy itself (58-60, 68-9). Meanwhile, as a statesman directly involved in Britain's trans-Atlantic expansion, ${ }^{10}$ he is well positioned to ask that the agents and merchants overseas pitch in and collect the data needed for the construction of a comprehensive natural history. ${ }^{11}$

The Baconian interpreters of nature are not passive with respect to this global data gathering. To the contrary, they instruct the gatherers with an exact method and an outline of the history to be compiled, so as to make the resulting history genuinely useful to the philosophers (Bacon, 2000, p. 223-32). To this end, the gatherers are confined to the realm of facts. Although they may pose "questions," these must be "not of causes but of fact," meant only to inspire further investigation on the part of the philosophers. ${ }^{12}$ All in all, Bacon emphasizes, the descriptive history of nature is so fundamental that it must be "composed with utter scrupulousness, as if an oath had been taken about the truth of every detail; for it is the volume of the works of God, and ... like a second Scripture" (231). This reference to the oath of truthful testimony resonates with Bacon's ensuing statement, which prefigures Kant's use of the judge-witness metaphor to describe how reason approaches nature in the B Preface ${ }^{13}$

(to use the language of civil procedure) we intend, in this Great Suit or Trial, given and granted by the goodness and providence of God (by which the human race seeks to recover its right over nature), to crossexamine nature herself and the arts on the articles of the case. $(232)^{14}$

Following this statement is a list of 130 articles for "Particular Histories." The largest category is on "Histories of Man," covering articles 41 through 128. Here are a few telling examples:

\footnotetext{
10 On the early formation of the British empire, see Canny 1998, which makes clear that the terms 'British' and 'empire' should be regarded with caveats here. Also see Ash, 2004, which situates Bacon's natural philosophy in the history of England during the reign of Queen Elizabeth I (1558-1603), when England emerged as a great naval power and its global explorations and trades grew significantly as a result. On the entanglement between Bacon's political and philosophical interests, see Irving, 2008, pp. 23-46; Zeitlin, 2021. Similarly, Boyle had deep ties to England's imperial projects (Irving, 2008, pp. 69-92; Malcolmson, 2013, pp. 15-21). So did the entire Royal Society (Irving, 2008, pp. 93-108).

11 The appeal to merchants may be additionally significant, thanks to the thenrevolutionary method of double-entry bookkeeping (Poovey, 1998, pp. 29-91). On the characteristics of the Baconian natural history, especially as regards its complex relation to natural philosophy, see Anstey, 2012. On the lasting impact of the program of Baconian natural history on the Royal Society (through the late eighteenth century), see Gascoigne, 2009.

12 On what Bacon (and his followers) meant by 'fact,' see Poovey, 1998, pp. 7-15, 97-120; Shapiro, 2000.

13 Kant chooses a statement by Bacon as the epigraph for the B/1787 edition of the Critique.

${ }^{14}$ Bacon's background as a lawyer is relevant here (Shapiro, 2000, pp. 8-33).
} 
41. History of the Figure and external Members of Man, his Size, Frame, Face and Features; and of their variations by People [Gentes] and Climate, or other minor differences.

52. History of different Conditions of the Body; Fatness, Thinness; of the so-called Complexions, ${ }^{15}$ etc.

\section{History of the Passions; as of Anger, Love, Shame etc.}

78. History of the Intellectual Faculties: Thought, Imagination, Discourse, Memory etc. (235-36).

Bacon grants that he has thereby provided only an outline, leaving it to later philosophers to "give detailed instructions by putting the questions that most need to be investigated and written up in each history" (232).

The Royal Society would take up this task. In the process, skin color, which did not appear in Bacon's list, would emerge as a distinct subject of philosophical interest. Boyle would play a formative role in this regard. Besides devoting a section, known as "Experiment XI," to the "blackness of Negroes" in one of his most important scientific works, Experiments and Considerations Touching Colours (1664, p. 151-67), Boyle also published a short piece titled "General Heads for a Natural History of a Countrey, Great or Small" (1666). This piece explicitly answers the Baconian call for "the Composing of a good Natural History, to superstruct, in time, a Solid and Useful Philosophy upon" (1666, p. 186). The heads somewhat mirror Bacon's articles. A notable difference is that Boyle's instruction about humans has an added reference to skin color:

there must be a careful account given of the Inhabitants themselves, both Natives and Strangers, that have been long settled there: And in particular, their Stature, Shape, Colour, Features, Strength, Agility, Beauty (or the want of it) Complexions, Hair, Dyet, Inclinations, and Customs that seem not due to Education. (1666, p. 188)

Boyle might have two philosophical reasons for wanting data about skin color. First, the climate hypothesis, which attributes black skin to the scorching heat of Equatorial Africa, remained popular in spite of Boyle's forceful objections to it in the Colours (1664, p. 152-59). ${ }^{16}$ More data about the skin colors of both natives and long-settled strangers in each climate might lend further counter-evidence against that hypothesis. Second, Boyle needed to substantiate his own proposition in the Colours that "Negroes" are descendants of Adam as much as the white Europeans are (166), ${ }^{17}$ by showing how it is possible for a supposedly white ancestor to produce his first black son(s), who would then somehow propagate hereditarily black offspring to posterity. Boyle's view on this matter in the Colours was uncertain. At one point, he cited a few anecdotal testimonies to the effect that, like Europeans, blacks are born white, although their

\footnotetext{
15 'Complexion' here does not mean what we now take it to mean (color, texture, or appearance of skin). Rather, it means the proportioned combination of four humors (cold or hot, and moist or dry), which determines the bodily habit and temperament. See "complexion, $n$." in my bibliography.

16 Boyle builds his argument against the climate hypothesis largely on the data extracted from newly available travel reports, such as those "by the best Navigators and Travellers to the West Indies" and to the New World in general (1664, p. 153-54). Many other prominent members of the Royal Society supported the climate hypothesis, however, and the hypothesis would continue to be debated and revised in response to objections (Malcolmson, 2013, pp. 65-6, 73-5).

17 Boyle's target here is Pre-Adamism (a version of polygenism), which challenges the Biblical account of single human origin (Adamism or Biblical monogenism) and holds instead that God created different peoples and different civilizations - e.g., the Chinese, Egyptians, and Ethiopians - in different parts of the world before there was Adam. On the history of Pre-Adamism and its impact, see Livingstone, 2008. On its role in the debates about racial differences in the seventeenth-century natural philosophy, see Smith, 2011. On Boyle's attempts to defend Biblical monogenism, see Malcolmson, 2013, pp. 65-112.
}

color changes to perfect blackness in a few days-presumably to suggest that the original seed of blacks, being Adam's descendants, is still white (164-66). Such a conjecture cannot stand on a few anecdotes, of course. It must be tested against more systematic, methodically collected data.

Regardless of Boyle's own philosophical agenda, the "General Heads" played an instrumental role in focusing the natural philosophers' and, through them, the global data gathers', attention on skin color. As Cristina Malcolmson summarizes its effect,

Boyle's desire to gather information about color and culture expanded into a multifaceted system in which the reports of European travelers worldwide evoked new sets of queries, and consequently new reports. ... these reports started to reproduce each other, such that a passage of observations on skin color ... became a standard part of travelers' narratives .... Thus the Society produced a new discourse on the causes of skin color[.] (Malcolmson, 2013, p. 63)

The Royal Society would also play a pivotal role in making meaning of the data gathered under direct or indirect influences of Boyle's "General Heads." 18 The link between skin color and the question of "race" would thereby become ever more salient. While Boyle used the expression 'Race of Negroes' once in the Colours (1664, p. 166), he attached no philosophical significance to it. This would change toward the end of the seventeenth century. One topic discussed at a Royal Society meeting in March, 1690 was "the Colours of Animalls, and particularly of the Negroes, whether it was the product of the Climate or that they were a Distinct race of Men." ${ }^{, 19}$ Although it is unclear what the fellows at the meeting understood by 'race,' it is significant that they brought up race besides the climate hypothesis, presumably as an alternative explanation of the blackness of "Negroes." ${ }^{20}$ If climate is only an external factor, race points to an internal cause.

Regardless of how the debates over these competing explanations unfolded next, ${ }^{21}$ it is certain that Kant entered the fray at a time when a rich trove of travel reports about non-Europeans had been produced. Such reports can be easily compared with one another precisely because the authors were largely responding to similar questions, knowingly or otherwise. ${ }^{22}$ Importantly, because the reports can be cross checked, this may serve as a pressure for each traveler to be as truthful in his report as possible - at least out of "honor," as I quoted Kant as claiming in section 2.2 .

\footnotetext{
18 On the relation between Boyle's "General Heads" and other queries issued by the Royal Society, see Hunter, 2007, pp. 12-21; Malcolmson, 2013, pp. 37-64. On the early Royal Society's efforts to continue the Baconian project of compiling a universal natural history by soliciting and regulating travel reports, see Carey, 1997. For a general account of the natural philosophers' involvement in the global data gathering, see Rubiés, 1996.

${ }^{19}$ Cited in Malcolmson, 2013, p. 65. Malcolmson also notes that "Negroes a distinct race of men" was a category for recording the minutes of the Society's meetings from 1685 and 1690 (2013, p. 69).

${ }^{20}$ Another commonly invoked explanation is the so-called Curse of Ham, typically in the context of justifying slavery (Goldenberg, 2017). Boyle rejected this hypothesis, according to which "the Blackness of Negroes [was] an effect of Noah's Curse ratify'd by God's, upon Cham," partly on methodological grounds. Although a "Naturalist" may believe in Biblical stories, he contends, immediately appealing to a supernatural cause in this case would amount to "Shifting off the Difficulty, instead of Resolving it; for we enquire not the First and Universal, but the Proper, Immediate, and Physical Cause of the Jetty Colour of Negroes" (1664, p. 159-60). This may be the reason why the Royal Society fellows would no longer take the Curse of Ham seriously in their natural-philosophical inquiries about the cause of black skin.

${ }^{21}$ For an overview of subsequent debates about the cause of skin color (especially blackness), see Mazzolini, 2014.

${ }^{22}$ Even if later travelers were no longer explicitly answering a given set of queries, they presumably modeled their reports on the earlier ones.
} 
Kant alludes to this critical comparison of travel reports when he expresses the following wish to anyone who "undertakes as a philosopher a universal natural history [Naturgeschichte] of the human being",23

a historical-critical mind [historisch-kritischer Kopf] had done all the preliminaries for them, picking out from the immeasurable multiplicity of ethnographic descriptions or travel narratives and all their conjectural records belonging to human nature, especially those in which they contradict one another, placing them next to one another (yet also with added reminders on the credibility of each narrator); for then no one would so rashly base himself on one-sided accounts, without first having weighed them precisely against the records of others. (RezHerder, 8:61-2)

Kant himself did part of the preliminary work of sorting and weighing travel reports in late 1750s. He did so mainly to equip his students with knowledge of the world (Weltkenntnis) through his course on physical geography. ${ }^{24}$ Reflecting his belief that the reports by modern travelers were generally more reliable than ever before in history (as I explained in 2.2), he wrote in his first announcement about the course (1757):

The rational taste of our enlightened times has presumably become so general that one can assume that one will find only a few persons who are indifferent to the Earth's natural peculiarities in regions outside their own. Nor should it be regarded as a lesser advantage that credulous admiration, the source of endless fantasies, has yielded to careful examination, which allows us to draw reliable conclusions from verified reports without the risk of becoming lost in a world of fables instead of attaining a proper science of noteworthy natural phenomena. (EACG, 2:3)

Kant's physical geography is precisely concerned with the "natural peculiarities" around the world. Specifically, it "considers the natural characteristics of the globe and what is on it," including human beings along with non-human animals, plants, minerals, and so forth (2:3). As someone who barely ventured beyond Königsberg, Kant was nevertheless confident that he was sufficiently equipped to offer such a course. Underlying this confidence was an appreciation of the recent explosion of travel reports, which in his view contained trustworthy testimonies about foreign regions of the Earth.

I have used all sources, sought out all information, and, in addition to what the works of ... Buffon [and other geographers] ... contain in the way of the general fundaments of physical geography, I have gone through the most thorough descriptions of individual countries by capable travellers ... and I have constructed a system out of everything relevant to my purpose. (2:4)

In the ensuing outline of physical geography, Kant specifies that human beings, as part of the animal kingdom, "are considered and compared in respect of their differences in natural form [Bildung] and colour in various regions of the Earth." He plans to "go through all the countries of the Earth in a geographical exposition," partly to "explain those tendencies of human beings that are derived from the [climate] zone in which they live, the manifold of their prejudices and mentality" (2:9, translation amended).

This was in fact what Georges Buffon (1707-88), who Kant mentioned in the passage quoted above, did to differentiate "varieties of the human species" (1749). It was reportedly by "comparing the

\footnotetext{
${ }^{23}$ Kant distinguishes two senses of Geschichte. One refers to "the Greek historia (narrative, description)," better called "physiography" (physical geography); the other, "physiogony," designates "the investigation of origin in nature" (GTP, 8: 162-63; 163n.). The former captures the Baconian natural history, while Kant means the latter when he talks about doing natural history as a philosopher (without thereby discounting the importance of Baconian history as historical cognition).

${ }^{24}$ On the significance of Kant's notion of Weltkenntnis, see Bianchi, 2018.
}

testimonies of travellers," which described various peoples around the globe in terms of their skin color, physical form, mode of living, customs, and so on, ${ }^{25}$ that Buffon determined whether, for instance, two peoples belong to the same or different "races" (Buffon, 1812, p. 379). ${ }^{26}$ He also defended the climate hypothesis, albeit in a significantly modified form, based on critical comparisons of relevant traveler reports (372-74, 405-7, 434-46). Once again, such comparisons are possible partly thanks to the earlier Baconians' instructions that helped to standardize the reports, which can then be measured against one another under a few general heads. $^{27}$

This brief note about Buffon also suggests that ethnographic data do not speak for themselves. Each side in the debate over the climate hypothesis-Boyle as its objector versus Buffon as its champion-can make their position compatible with the same dataset. Generally, from Kant's standpoint, one can make something out of historical cognitions only with the eye of a philosopher. The view of the latter is inevitably perspectival, so that the philosopher may have to decide between competing principles by which to interpret the empirical data. Kant's own approach to race perfectly illustrates this point:

from a multiplicity of descriptions of countries one can prove, if one wants to, that ... Americans and Negroes are each a race, sunk beneath the remaining members of the human species in their mental predispositions, but on the other side by just as apparent records that as regards their natural predispositions, they are to be estimated equal to every other inhabitant of the world; so it remains to the choice of the philosopher whether he wants to assume differences of nature or wants to judge everything in accordance with the principle [all is as with us]. (RezHerder, 8:62, italics added) ${ }^{28}$

At some point, the philosopher will have to defend his choice of a particular principle against the charge of another philosopher. Such a defense will have to take place in a setting that differs from the inquisitorial/civil-law court, but instead has the structure of an adversarial/common-law court, where the opposing parties bring different judicial principles to the table as relevant to the case. This controversy over principles has to be settled before one can decide what sort of testimonial evidence to seek from witnesses. This, as we shall see, captures what Kant would do in his work on race.

\subsection{Kant's use of travel reports in theorizing about race as a natural philosopher}

Kant has three dedicated publications on race from mid-1770s through late 1780s: "Of the Different Races of Human Beings" (1775/ 7), "Determination of the Concept of a Human Race" (1785), and "On the Use of Teleological Principles in Philosophy" (1788). All three argue for these main propositions:

(1) there are four principal races by skin color—white, yellow, black, and copper-red;

(2) skin color is the sole basis for this racial classification because, of all the human characteristics that are hereditary, this alone is unfailingly so;

\footnotetext{
25 For a critical analysis of Buffon's (and many other eighteen-century philosophers') relation to travel literature, see Duchet, 1995, pp. 65-136. The literature on black Africans, in particular, shaped Buffon's speculations about them (Curran, 2011, pp. 29-73).

26 "Variétés dans l'espèce humaine" was originally published in Buffon, 1749, p. 371-530. I am using the pagination of its English translation in Buffon, 1812, pp. 302-446.

27 Buffon analyzes the travel reports about human populations according to "three heads: 1 . The colour; 2 . The figure and stature; and, 3. The dispositions of different people" (1812, p. 302).

${ }^{28}$ Kant stresses difference in his theory of race (BBM, 8:99).
} 
(3) different races nevertheless belong to the same human species, with a common phyletic origin.

Philosophically, Kant is most interested in showing that his theory of race provides the best model for explaining hereditary differences among humans. He sees this as an exercise in natural philosophy: in the 1788 essay on race, he invokes a jury of philosophical investigators of nature (Naturforschern) to adjudicate his dispute with Georg Forster, who published a critique of his 1785 essay. ${ }^{29}$ Remarkably, Kant mentions the civil-law metaphor of an inquisitorial court before invoking the commonlaw imaginary of a jury.

I fear nothing from a court of inquisition [Ketzergericht] for Hr. F.'s system (for it, too, would presume a jurisdiction outside of its domain). Moreover, if necessary, I vote for a philosophical jury ... of mere investigators of nature, and yet do not believe that their ruling would be in his favor. (GTP, 8:179)

In an inquisitorial/civil-law court, as I explained in 2.1, the judge establishes facts by interrogating witnesses and then arrives at a verdict according to the legal codes that he has chosen according to his understanding of the case. Kant finds it inappropriate to take his dispute with Forster to such a court, however, where the judge has no authority to resolve the higher-order controversy over which of the many laws are truly pertinent. If such a controversy must be settled by a just procedure, Kant prefers a common-law court, where a philosophical jury can hear out the competing sides. Although the jurors as Naturforschern may have fundamental disagreements among themselves, they at least share the interest in working "the fertile soil of the investigation of nature" so as to gain, say, a better understanding of a given phenomenon (GTP, 8:180). Kant is confident that such a jury of philosophical investigators would not rule against him.

Kant has already laid much of the ground for this confidence in his 1785 essay on race. He begins this essay by acknowledging the existence of voluminous travel reports about human differences, only to highlight the need for philosophical investigation.

The knowledge [Kenntnisse] which the new travels have disseminated about the manifoldnesses in the human species so far have contributed more to exciting the understanding to investigation on this point than to satisfying it. It is of great consequence to have previously determined the concept that one wants to elucidate through observation before questioning experience about it, for one finds in experience what one needs only if one knows in advance what to look for. (BBM, 8:91, italics added)

The italicized parts suggest that Kant's concern is to figure out what one must know before one can interrogate nature so as to understand it. Regarding human differences, he deems it critical to determine the concept of race-as opposed to variety, species, and so on-beforehand. This concept, by Kant's analysis, "contains first the concept of a common phylum, second necessarily hereditary characters of the classificatory difference among the latter's descendants" (BBM, 8:99). Such a concept, he later contends, is "well grounded in the reason of each observer of nature who infers from a hereditary particularity of different interbreeding animals that does not at all lie in the concept of their species a common cause, namely a cause that lies originally in the phylum of the species" (GTP, 8:163). The reference to the "observer of nature" is significant. In Kant's view, "one must be guided by a determinate principle merely in order to observe, i.e., to pay attention to that which could indicate the phyletic origin"- -so much so that "Someone who has not made his investigation according to that principle will have to search again" (8:164; see 8:161).

\footnotetext{
${ }^{29}$ Forster 1991(1786). On the debate between Forster and Kant, see Gray, 2015; Goldstein, 2019, pp. 92-104.
}

The principled observation in Kant's case comes down to an examination of the available travel reports according to the conceptual scheme and philosophical principles established a priori. In so doing, he already knows what kind of testimonial evidence to seek out in those reports. First, he needs evidence for his claim that skin color is the only human characteristic that is contingent-i.e., does not follow from the essence of human species (BBM, 8:96, 99)—and unfailingly hereditary. ${ }^{30}$ To Kant, what establishes the unfailing heredity of a characteristic is the "law of necessary half-breed generation": skin color alone fits the bill because two parents with different skin colors always produce offspring with a hybrid color, whereas no other reported human differences are hereditary in this way (8:94-6). Kant's summary of the evidence for this proposition suggests that he has combed through a good number of travel reports for affirming testimonies. He also seems aware of the need to explain away reports that contain apparent counterevidence, such as reports of non-whites producing white children (albinos).

The white man with the Negro woman and vice versa produce the mulatto, with the [Eastern] Indian woman the yellow mestizo and with the American the red mestizo; the American with the Negro produce the black Caribbean, and vice versa. (The mixing of the Indian with the Negro has not yet been attempted.) In heterogeneous mixing the character of the classes is unfailingly hereditary, and there are no exceptions to this. Where one finds [such exceptions] cited, there is a misunderstanding at bottom in that one took an albino or kakerlak (both deformities) for a white. (BBM, 8:95) ${ }^{31}$

The strongest evidence for the unfailing heredity of skin color, Kant submits, is the kind collected about people that have been transplanted to an entirely different climate and have started reproduction in this new environment, such as the "Negroes" (BBM, 8:92) and the "gypsies" (GTP, 8:172) who have long resided in or are born in Europe (or America).

Next, Kant needs evidence for his hypothesis that hereditary human differences must nevertheless be derivable from a common cause, which consists in certain germs (Keime) and predispositions (Anlagen) that lie in the original human phylum (Stamm). Before subjecting such a hypothesis to empirical verification (to establish its probability), though, he needs to show that it is well formed and tested against competing hypotheses "under the strict oversight of reason" (A770/B798; see B115; Lo-Wien, 24:887-89). His procedure for assessing the competing modes of explanation is as follows.

I, for my part, look only at the particular maxim of reason from which each person departs and according to which he generally manages to find facts which favor it; and afterward I seek out my maxim, ... Now if I find my maxim proved, exactly in keeping with the use of reason in natural science the only one fit for a consistent mode of thought, then I follow it without heeding those alleged facts, which borrow their credibility and sufficiency for the assumed hypothesis almost exclusively from that already chosen maxim and to which facts one can moreover oppose a hundred other facts without effort. (BBM, 8:96)

Thus, Kant seeks to exclude various alternatives a priori, even if they can be made compatible with phenomena. First off, the approach that invokes God's special, purposeful creations (VRM, 2:440) is unacceptable because "in natural science everything must be explained naturally" (GTP, 8:178). A second approach "places all differences in our species on ... chance," which explains nothing and so cannot satisfy the philosophical investigator of nature (GTP, 8:168). Yet another approach traces hereditary differences to human interventions, speculating that "flattened noses"

\footnotetext{
${ }^{30}$ Kant contrasts skin color with other contingent differentials of humanity. For instance, there are blondes versus brunettes. While this difference is also hereditary, it is not unfailingly so (VRM, 2:430-31; GTP, 8:165-68).

31 On the significance of albinos in the discourse about race before Kant (especially in Buffon's), see Curran, 2009. 'Kakerlak' is a term for albino that literally means cockroach.
} 
in a people, for instance, were "at first artificially given by parents to new-born children and then supposedly taken up by nature into her generative power." Permitting this sort of explanation, Kant warns, would breach the bounds of reason beyond repair, as "delusion forces itself through this breach in thousands." No proper understanding of phenomena is gained thereby, which demands causal explanations that can be brought under a system of constant laws of nature (BBM, 8:96-7).

The requirement that everything in natural science be explained naturally also "indicates the boundaries of natural science." This allows Kant to dismiss a fourth approach, which introduces "self-concocted powers of matter following unheard-of and unverifiable laws." This mode of explanation has "gone beyond natural science," as it is impossible for us to confirm the proposed explanatory ground "by experience" (GTP, 8:178-79). Thus, it is not enough that the investigator proposes a natural cause to explain the given phenomenon. He must show that his explanation accords with known/knowable laws of nature and that the proposed cause can, in principle, be ascertained by possible experience. Otherwise, there would be no end to ad hoc hypotheses: "it would take no effort for reason to explain whatever and however it wants" (8:182).

The only viable alternative left at this point seems to be the "physicalmechanical mode of explanation" (GTP, 8:179), which explains hereditary differences solely by appealing to "the universal mechanical laws" (VRM, 2:435) or to "the mere mechanical influences of external causes," such as climate (Rez-Herder, 8:62). Kant rejects this explanatory model as well. For sure, a purely mechanical explanation would receive its recommendation, as would some of the aforementioned explanations, from "an otherwise wholly correct maxim of reason," namely that one should not unnecessarily multiply explanatory grounds (BBM, 8:96). No "physical-mechanical causes can produce an organic body," however, let alone "add something to its generative power, i.e., bring about something that propagates itself" (VRM, 2:435).

Kant's own approach lies somewhere between the last two alternatives. Although the maxim of not unnecessarily multiplying explanatory grounds rules against assuming "special first powers of nature or created predispositions" to explain phenomena, Kant limits this maxim by another, namely that nature always preserves itself. According to the latter maxim, "throughout all of organic nature in all changes of individual creatures their species is preserved unchanged" (BBM, 8:96-7). Thus, nature must have equipped each organic species with "hidden inner provisions [in the form of certain original germs and predispositions] for all kinds of future circumstances, so that it may preserve itself and be suited to the difference of the climate or the soil" (VRM, 2:434). Meanwhile, the natural philosopher must be able to connect the current state of things with those original causes "according to laws of efficient causality" (GTP, 8:161-62). In particular, one must show how-by what law-governed efficient-causal mechanisms-hereditary characteristics may have resulted from "a gradually developing original predisposition placed into the phylum and restricted to a certain number according to the main differences of the influences exercised by the air [and sun]" (8:177).

Regarding the human species, Kant sees skin color as what most ostensibly attests to the "self-help of Nature by means of a certain organization" (VRM, 2:439). He includes air and sun as "those causes which most deeply influence the generative power and produce an enduring development of the germs and predispositions" (VRM, 2:435-36). How the original germs and predispositions would develop during the first period of human existence depends on the particular climate in which the most ancient dwellers had to adapt and preserve themselves. There being exactly four climate types in terms of air and sun (humid cold, dry cold, humid heat, and dry heat), four distinct skin colors, marking four principal races, were formed as a result of long periods of adaptation to those climates (white, copper-red, black, and yellow). In sum,

the germs which were originally placed in the phylum of the human species for the generation of the races must have developed already in most ancient times according to the needs of the climate, if the residence there lasted a long time; and after one of these predispositions was developed in a people, it extinguished all the others entirely. (BBM, 8:105)

Reason must be "favorably disposed" to this mode of explanation, Kant reassures himself later, because "with the least possible appeal to the supernatural, [it] leaves everything that follows from the first beginning to nature" and therefore still "leaves natural mechanism an ... unmistakable role" to play in accordance with empirically known/ knowable laws of nature (KU, 5:424).

What is the natural mechanism behind the formation of the four basic skin colors? Kant, conjecturally, describes it as some sort of "procedure for continuously removing what irritates the circulation of the blood," especially in view of the fact that "all animal blood contains iron" (VRM, $2: 439-40$ ). He specifies this procedure in terms of the chemical theory that assumes phlogiston and (acidic and alkaline) salts as the basic agents:

the saline acidic or the phosphoric acidic or the volatile alkaline in the evacuating vessels of the skin would precipitate the iron particles in the reticulum as red or black or yellow. In the white, however, this iron that is dissolved in the fluids would not be precipitated at all and thereby would indicate at once the perfect mixture of the fluids and the strength of this human sort ahead of the others. (2:440)

Like previous natural philosophers who speculated about the cause of skin colors, Kant regards the blackness of "Negroes" as the paradigmatic example. This is also when he most readily invokes travel reports, albeit only the ones that support his conjecture:

the human blood becomes black ... merely by being overloaded with phlogiston. ... the true Negroes live in regions in which the air is so phlogistized through thick forests and swamp-covered regions, that it is, according to [James] Lind's report [An Essay On Diseases Incidental to Europeans in Hot Climates (1768)], deadly peril for the English sailors to navigate up the Gambia River even for one day in order to buy meat there. ${ }^{32}$ Thus it was an arrangement very wisely made by Nature to organize their skin such that the blood, since it does not by far sufficiently remove enough phlogiston through the lungs, could dephlogistize itself much more strongly through the skin than is the case with us. (BBM, 8:103)

The remaining skin colors may be similarly explained, Kant claims, by analogy. Citing more reports (again selectively), he surmises, for instance, that the need to rid the blood of excessive aerial acid has caused "the red rust color which distinguishes the skin of the Americans"; and the need to remove volatile alkaline, which blood is "especially liable to produce ... excessively" in dry heat, explains the (Eastern) Indian race $(8: 103-4) .^{33}$

Kant admits that these conjectures may not be compelling (VRM, $2: 440$ ). In a polemic context, though, what matters to him is simply that he can show how the phenomena of hereditary peculiarities such as skin colors are possible under the premise that there are certain germs and predispositions contained in the human phylum, which develop differently under different material conditions (climates). His conjectures in this respect are "at least equally plausible [scheinbaren]" as the competitors. ${ }^{34}$ Thus, they are "at least good for addressing an opponent who,

\footnotetext{
32 Following Buffon (1812:383), Kant locates "true Negroes" in the Senegal-Gambia region. His (not Buffon's) reason is that the air there contains so much phlogiston that only those with the blackest skin have survived it (BBM, 8:103; VRM, 2:441-42; GTP, 8:169-70n.).

${ }^{33}$ See Gorkom, 2020 for a further explication of the role of phlogiston in Kant's theory of race, as well as the circumstances in which he was slow to acknowledge that the phlogiston theory had been entirely falsified by some of his contemporaries.

34 On plausibility (contra probability), see Lo-Blom, 24:143-46; JL, 9:81-2.
} 
when he has no sound objection against the major premise [Hauptsatz], triumphs over the fact that the assumed ground [Princip] cannot even make the possibility of the phenomena comprehensible" (GTP, 8:104, translation amended).

This account of Kant's reasoning further showcases his view that testimony is entirely subservient to reason (as I explained in section 2). If the available travel reports were largely generated under direct or indirect influences of the Baconian natural philosophers in the first place, ${ }^{35}$ now Kant, in an attempt to make some philosophical sense of them, subjects them to additional rational constraints (e.g., which maxim of reason has priority in guiding the Naturforscher's effort to explain certain differences among humans, and under what conditions the Naturforscher can rightfully accept a proposed hypothesis and use it to interrogate the data). In this way, he can see himself as justified in selectively summoning some travelers to testify, doing so only after he has defended his major principle or ground of explanation a priori. So, what (if any) kind of uptake a given report receives in his theorizing about race hinges on what he has decided, in advance, to seek in it. We will recognize the hazard of this approach when we see what other testimonies Kant invokes.

\section{A call for further investigation}

A crucial point about Kant's theorizing of race in three dedicated essays is his continued appeal to the Naturforschern's viewpoint. When he makes this appeal explicit in the 1788 essay, he is responding to Forster's invocation of a bona fide philosophical jury (ächte philosophische Jury) (Forster, 1991, p. 156). Importantly, however, Forster appeared to be calling for a jury of moral philosophers, as the call came right after an impassioned reflection on the impact that a theory of race like Kant's may —or may not—have on the cruelties of slavery (1991, p. 154-55). Kant declines this invitation to consider the practical implications of his theory, insisting instead that a jury of Naturforschern be called to adjudicate his controversy with Forster. This move by Kant deserves a thorough investigation, which I urge interested scholars to take up.

For now, let me briefly return to the subject of testimony. I have yet to mention the most disconcerting example of Kant's selective use of testimonies. In an attempt to counter Forster's argument for a "second transplanting," admittedly the "the most important counterargument" to his claim about the persistent heredity of skin colors (GTP, 8:172), Kant reaffirms that, once certain germs in the original human phylum were developed in a population to suit a given climate, nature "indeed paid no heed to a transplanting after[wards]." As evidence, he claims that, when some of the already adapted inhabitants of the old world were driven to a new climate, they "have never been able to bring about in their progeny (such as the Creole Negroes, or the Indians under the name of the gypsies) a sort that would be fit for farmers or manual laborers" (8:173-74). Kant then cites the damning testimony about freed former slaves by the anti-abolitionist merchant James Tobin (against the abolitionist reverend James Ramsay) - to show that "Negroes do not bring any more of this impetus [to activity] into other climates and pass it on to their offspring than was needed for their preservation in their old motherland and had been received from nature" (8:174n.; see VRM, 2:438).

\footnotetext{
${ }^{35}$ I do not mean to claim that there were clearly traceable causal links between Bacon's vision about a universal natural history, on the one hand, and how natural philosophers like Buffon and Kant came to theorize about human differences, on the other. I only wish to foreground the larger historical and intellectual context in which Kant both trusted the vast amount of global travel reports available to him and felt the urge to shed some much-needed light on the phenomena reported. His repeated efforts to establish a natural-scientific racial classificatory system was a continuation of the systematic taxonomical work that began in earnest only during the second quarter of the eighteenth century. Overall, such work was a philosophical response to the "information overload" resulted from the preceding decades of global data gathering (Müller-Wille \& Charmantier, 2012).
}

To give some context here, Ramsay published a book in 1784, An Essay on the Treatment and Conversion of African Slaves in the British Sugar Colonies, to argue for abolition based on personal observations from his extensive missionary work in the colonies. Ramsay devotes an entire chapter to debunking various arguments for the supposed inferiority of "Negro" slaves-from philosophy or "hypothesis" (for instance, by Hume in his well-known "Essay on National Characters"), from outer form (e.g., skin color), from anatomy (of skulls), and from observation-before "prov[ing] their natural powers from reason and experience" (1784, p. 197-262). The punchline of Ramsay's proof is that "there is no difference between the intellects of whites and blacks, but such as circumstances and education naturally produce" (203, italics added). At the very least, he asks, "why seek for causes less consistent, apparently less worthy of the Deity, to pamper vanity and pride, when this [consideration of circumstances and education] is full and sufficient to explain the fact" (209)?

Tobin countered Ramsay's argument with fervor in a tract titled Cursory Remarks upon the Reverend Mr. Ramsay's Essay ... (1785). ${ }^{36}$ An abbreviated German translation of this tract, along with that of Ramsay's essay, is included in the fifth volume of the Beiträge zur Völker und Länderkunde edited by the geographer and historian Matthias Christian Sprengel (1786). ${ }^{37}$ Among other things, Tobin preempted any circumstantial explanation of the freedmen's alleged disinclination for work (1785, p. 116-22). Kant summarizes this part of Tobin's argument as follows.

The same author notes on this matter that it is not the northern climate that makes the Negroes disinclined for labor. For they would rather endure waiting behind the coaches of their masters or, during the worst winter nights, in the cold entrances of the theaters (in England) than to be threshing, digging, carrying loads, etc. (GTP, 8:174n.)

Kant gives an exceptional degree of credence to Tobin's testimony (how often do we see him so unreservedly trusting another man's testimony?), even though his own theory of testimony suggests that he should be very skeptical of what a merchant invested in the slavery industry may have to say about the enslaved race. Alas, Kant seems eager to use Tobin's testimony to corroborate his hypothesis that, if a people exhibit a characteristic that appears unalterable in a new environment, this heredity can only be explained in the same manner that he has explained the heredity of skin color. ${ }^{38}$

What kind of argument is that? I ask this question rhetorically. Given his account of the dynamics between the judge and lawyers (section 2.1), Kant's defense against Forster's charge fits the bill of a "lawyer's proof" (A430/B458). Granted, unlike the lawyers he derides, Kant may have no intention to deceive (his intention is not my concern anyways). Still, his response to Forster hinges on two deceptive moves. The first is his insistent appeal to a jury of mere Naturforschern, whereby he deflects any tough moral challenges to his theorizing of race. The second move consists in a one-sided presentation of the Tobin-Ramsay debate, so that the jury would not even hear an alternative explanation of why freed blacks appeared to be "tramps" (GTP, 8:174n.). A moderately competent judge should easily see through this second move. But it takes a genuinely wise

\footnotetext{
36 On the scope and historical significance of the Ramsay-Tobin debate, which went beyond the two publications I just mentioned, see Swaminathan, 2016.

37 The volume starts with Ramsay's essay (Sprengel, 1786, p. 1-74), while Tobin's appears toward the end (267-92). It is also worth noting that Sprengel himself lectured and published on the history of slavery and was evidently interested in exposing his German readers to anti-slavery ideas (Zhang, 2018). ${ }^{38}$ That is, there are germs in the human being that would develop into certain natural predispositions in a people as they adapted to their original climate; one such predisposition is an "immediate drive to activity," which is weaker or stronger depending on the needs of that original climate; once a people obtained a degree of this drive in accordance with the needs of their native environment, it became fixed as an "inner predisposition," which would extinguish in another climate just as little as their "externally visible" characteristic, namely their skin color (GTP, 8:174n.). For further explication, see Lu-Adler, 2021.
} 
judge to problematize the first. Such a judge would dismiss Kant-the-lawyer's request of a jury of mere Naturforschern. A debate about human differences that involves actual human beings, who moreover live in a racially oppressive world, should instead be subjected to the scrutiny of concerned moral experts. ${ }^{39}$

\section{References}

\section{Kant's Works}

A/B. (1998). Critique of pure reason. In Guyer, P. and Wood, A.(Trans.). Cambridge: Cambridge University Press.

Anth. (2007). Anthropology from a pragmatic point of view. In G. Zöller, \& R. Louden (Eds.), Anthropology, history and education (pp. 231-429). Cambridge: Cambridge University Press.

Anth-Mron. (2012). Anthropology mrongovius. In A. Wood, \& R. Louden (Eds.), Lectures on anthropology (pp. 335-509). Cambridge: Cambridge University Press.

BBM Determination of the concept of a human race. In Anthropology, op. cit., 145-159.

EACG. (2012). Plan and announcement of a series of lectures on physical geography. In E. Watkins (Ed.), Natural science (pp. 386-395). Cambridge: Cambridge University Press.

Eth-Collins. (1998). Moral philosophy, from the lectures of Professor Kant, Konigsberg, winter semester, 1784-5, Georg Ludwig Collins. In P. Heath, \& J. B. Schneewind (Eds.), Lectures on ethics (pp. 37-222). Cambridge: Cambridge University Press.

Eth-Vigil Notes on the lectures of Mr. Kant on the metaphysics of morals, Taken by Johann Friedrich Vigilantius. In Lectures on Ethics, op. cit., 250-452.

GTP On the use of teleological principles in philosophy. In Anthropology, op. cit., 195-218.

JL. (1992). The Jäsche logic. In Young, M. (Trans.), Lectures on Logic. (pp. 527-640). Cambridge: Cambridge University Press.

KU. (2000). Critique of the power of judgment. In Translated by Paul Guyer and Eric Matthews. Cambridge: Cambridge University Press.

Lo-Blom The Blomberg logic. In Lectures on logic, op cit., 1-246.

Lo-Wien The vienna logic. In Lectures on logic, op cit., 249-377.

MS. (1997). The metaphysics of morals. In Gregor, M. (Trans.), Practical philosophy (pp. 353-603). Cambridge: Cambridge University Press.

PG Physical geography. In Natural science, op cit., 434-679.

RezHerder Review of J. G. Herder's ideas for the philosophy of the history of humanity. Parts 1 and 2. In Anthropology, op cit., 121-142.

VRM Of the different races of human beings. In Anthropology, op. cit., 82-97.

\section{Other Works}

Anstey, P. (2012). Francis Bacon and the classification of natural history. Early Science and Medicine, 17, 11-31.

Ash, E. (2004). Power, knowledge and expertise in Elizabethan England. Baltimore: Johns Hopkins University Press.

Bacon, F. (2000). In L. Jardine, \& M. Silverthorne (Eds.), The new organon. Cambridge: Cambridge University Press.

Boyle, R. (1664). Experiments and considerations touching colours. London: for Herringman.

Boyle, R. (1666). General heads for a natural history of a countrey, great or small. Philosophical Transactions, 1, 186-189.

Buffon, G. (1749). Histoire Naturelle, Generale et Particuliere (Vol. III). Paris: De l'Imprimerie Royale.

Buffon, G. (1812). Natural history, general and particular (Vol. III). London: for Cadell et al. Smellie, W. (Trans.).

Canny, N. (Ed.). (1998). The oxford history of the British empire (Vol. 1). Oxford: Oxford University Press.

Carey, D. (1997). Compiling nature's history: Travellers and travel narratives in the early royal society. Annals of Science, 54, 269-292.

Cohen, W. (1980). The French encounter with Africans: White response to blacks, 1530-1880. Bloomington and Indianapolis: Indiana University Press.
Complexion, n. (June 2021). OED Online. Oxford University Press www.oed.com/view /Entry/37678. (Accessed 4 August 2021).

Curran, A. (2009). Rethinking race history: The role of the albino in the French enlightenment life sciences. History and Theory, 48, 151-179.

Curran, A. (2011). The anatomy of blackness: Science and slavery in an age of enlightenment. Baltimore: Johns Hopkins University Press.

de Bianchi, S. (2018). The stage on which our ingenious play is performed: Kant's epistemology of Weltkenntnis. Studies in History and Philosophy of Science, 71, 58-66.

Duchet, M. (1995). Anthropologie et histoire au siècle des Lumières. Paris: Albin Michel.

Forster, G. (1991). Noch etwas über die Menschenrassen (1786). In Georg Forsters Werke 8 (pp. 130-156). Berlin: Akademie-Verlag.

Gascoigne, J. (2009). The royal society, natural history and the peoples of the 'new world(s)', 1660-1800. British Journal for the History of Science, 42, 539-562.

Gelfert, A. (2006). Kant on testimony. British Journal for the History of Philosophy, 14, 627-652.

Goldenberg, D. (2017). Black and slave: The origins and history of the curse of ham. Berlin: Walter de Gruyter.

Goldstein, J. (2019). Georg Forster: Voyager, naturalist, revolutionary. Chicago: University of Chicago Press.

Gray, S. (2015). Kant's race theory, Forster's counter, and the metaphysics of color. The Eighteenth Century, 53, 393-412.

Hunter, M. (2007). Robert Boyle and the early royal society: A reciprocal exchange in the making of Baconian science. The British Journal for the History of Science, 40, 1-23.

Irving, S. (2008). Natural science and the origins of the British empire. London: Pickering \& Chatto.

Livingstone, D. (2008). Adam's ancestors: Race, religion, and the politics of human origins. Baltimore: Johns Hopkins University Press.

Lu-Adler, H. (2021). Kant on lazy savagery, racialized. Journal of the History of Philosophy (in press).

Malcolmson, C. (2013). Studies of skin color in the early royal society. London: Routledge.

Mazzolini, R. (2014). Skin color and the origin of physical anthropology (1640-1850). In S. Lettow (Ed.), Reproduction, race, and gender in philosophy and the early life sciences (pp. 131-161). Albany: SUNY Press.

Mikalsen, K. (2010). Testimony and Kant's idea of public reason. Res Publica, 16, 23-40.

Møller, S. (2020). Kant's tribunal of reason. Cambridge: Cambridge University Press.

Müller-Wille, S., \& Charmantier, I. (2012). Natural history and information overload: The case of Linnaeus. Studies in History and Philosophy of Science, 43, 4-15.

Newton, A. (2014). Kant on testimony and the communicability of empirical knowledge. Philosophical Topics, 42, 271-290.

Poovey, M. (1998). A history of the modern fact. Chicago: University of Chicago Press.

Ramsay, J. (1784). An essay on the treatment and conversion of African slaves in the British sugar colonies. London: Phillips.

Rubiés, J.-P. (1996). Instructions for travellers: Teaching the eyes to see. History and Anthropology, 9, 139-190.

Shapiro, B. (2000). A culture of fact: England, 1550-1720. Ithaca: Cornel University Press.

Shieber, J. (2010). Between autonomy and authority: Kant on the epistemic status of testimony. Philosophy and Phenomenological Research, 80, 327-348.

Smith, J. (2011). The pre-adamite controversy and the problem of racial difference in the 17th-century natural philosophy. In D. Marcelo (Ed.), Controversies within the scientific revolution (pp. 223-250). Amsterdam: John Benjamins Publishing Co.

Sprengel, M. C. (1786). Beiträge zur Völker und Länderkunde (Vol. 5). Leipzig: Weygandschen Buchhandlung.

Swaminathan, S. (2016). (Re)defining mastery: James Ramsay versus the West Indian planter. Rhetorica: A Journal of the History of Rhetoric, 34, 301-323.

Tobin, J. (1785). Cursory remarks upon the reverend Mr. Ramsay's essay on the treatment and conversion of African slaves in the sugar colonies. London: Wilkie et al.

van Gorkom, J. (2020). Skin color and phlogiston: Immanuel Kant's racism in context. History \& Philosophy of the Life Sciences, 42, 16. https://doi.org/10.1007/S40656-020$00311-4$

Zeitlin, S. (2021). Francis Bacon on imperial and colonial warfare. Review of Politics, 83, $196-218$.

Zhang, C. (2018). Matthias Christian Sprengel (1746-1803): Slavery, the American revolution, and historiography as radical enlightenment. In C. Niekerk (Ed.), The radical enlightenment in Germany: A cultural perspective (pp. 163-183). Leiden: Brill.

\footnotetext{
39 I presented the basic thesis of this paper at the Conference on Kantian Rationality in Philosophy of Science (October 9-11, 2020), organized by Thomas Sturm, Nina Dmitrieva, and Andrey Zilber. I thank the audience at the conference for the discussion. I am also grateful to the two reviewers for their instructive feedback on the two versions of this paper and to Thomas Sturm and Rudolf Meer for seeking out those reviewers.
} 